\title{
The Lizard in the Volcano: \\ Narratives of the Kuwae Eruption
}

Chris Ballard

In the fifteenth century, on the island of Kuwae in what is now Vanuatu, a blue-tailed skink, secreted within a yam tuber by a man named Tombuku and buried at the base of a casuarina tree, unleashed the second-largest volcanic eruption of the last two thousand years, destroying Kuwae and its remaining inhabitants and throwing enough pulverized rock and sulfur dioxide gas into the atmosphere and stratosphere to trigger a significant depression of the average global temperature and the onset of the Little Ice Age. Or so the stories go.

Curiously, what outsiders might regard as the actual events of the eruption of Kuwae are scarcely touched on by either of the two local stories that describe the causes and consequences of this hugely disruptive event and that are the focus of this article. Instead, the first story deals with the figure of Tombuku and the moral source of his anger, which becomes condensed in the form of the lizard-a story that ends with the first moment of the eruption and Tombuku's instant death. The second story addresses the aftermath of the eruption and revolves around the character of one of only two survivors left on Kuwae, who returns to the remnant island of Tongoa as Matanauretonga. As the first of the new island's chiefs, he sets in motion what is for contemporary narrators the much more consequential history of reclamation and recolonization.

Local narratives about Kuwae, its eruption, and its aftermath have been recounted in central Vanuatu over the past five centuries, but starting in at least the I 890 , outsiders also became aware of the Kuwae stories, which they documented and retold and which inspired them to investigate further. First missionaries, then voyagers and administrators, and later geologists, anthropologists, and archaeologists arrived on Tongoa and were guided to Kuwae by oral narratives and material traces, evaluating and

The Contemporary Pacific, Volume 32, Number I, 98-I 23

(C) 2020 by University of Hawai' $i$ Press 
reworking the older stories in new narratives of their own. The emerging global story of Kuwae enlists the eruption in histories of the impact across the planet of a massive fifteenth-century volcanic event, bringing new questions and new audiences into calculation.

For the purposes of this article, I distinguish between "stories," those tales or themes that enjoy broad recognition and acceptance within a community, and "narratives," their individual renditions or performances, each of which plays on but works within the theme of the story to introduce specific details and promote a particular perspective or interest. ${ }^{1}$ All narratives betray some degree of interest, some modification or addition (or omission) that may vary not just from narrator to narrator but also between versions told by the same narrator confronted with different audiences, different materials, or different goals. This is as true of local narratives of Kuwae as it is of the new stories being created and told about Kuwae on a global scale.

Space precludes a forensic examination and formal comparison of each of the fifty or more individual narratives about Kuwae documented since I 890, some of them fragmentary and others complete, some published and others documented on paper or in audio or video recordings and transcribed and translated for the first time from Nakanamanga, Namakura, Bislama, or French (Ballard 20I 8). ${ }^{2}$ Some of these versions are recountings by narrators from Tongoa and the surrounding Shepherd Islands (map I), while others are outsiders' retellings of local narratives, but all ground the truth of their claims in stories told locally in Vanuatu. As a precursor to the close, formal analysis that these narratives deserve, this article describes some of the contexts through which they might be approached and appreciated, describing their genesis as documents and the development of outsider awareness of the event of the eruption and its potential significance on a global scale. If we are to bring the stories and histories of Pacific communities into productive conversation with global stories and histories, we must first understand them on their own terms.

\section{Discovering Kuwae}

Standing at the head of a cliff near the village of Kurumambe in 20Io, overlooking the stretch of sea blasted out by the Kuwae volcano between what are now the islands of Tongoa and Epi in contemporary Vanuatu, a group of young men and women pointed out to me the rough location of the submarine vent of Karua, beneath which the lizard still lies. Then 


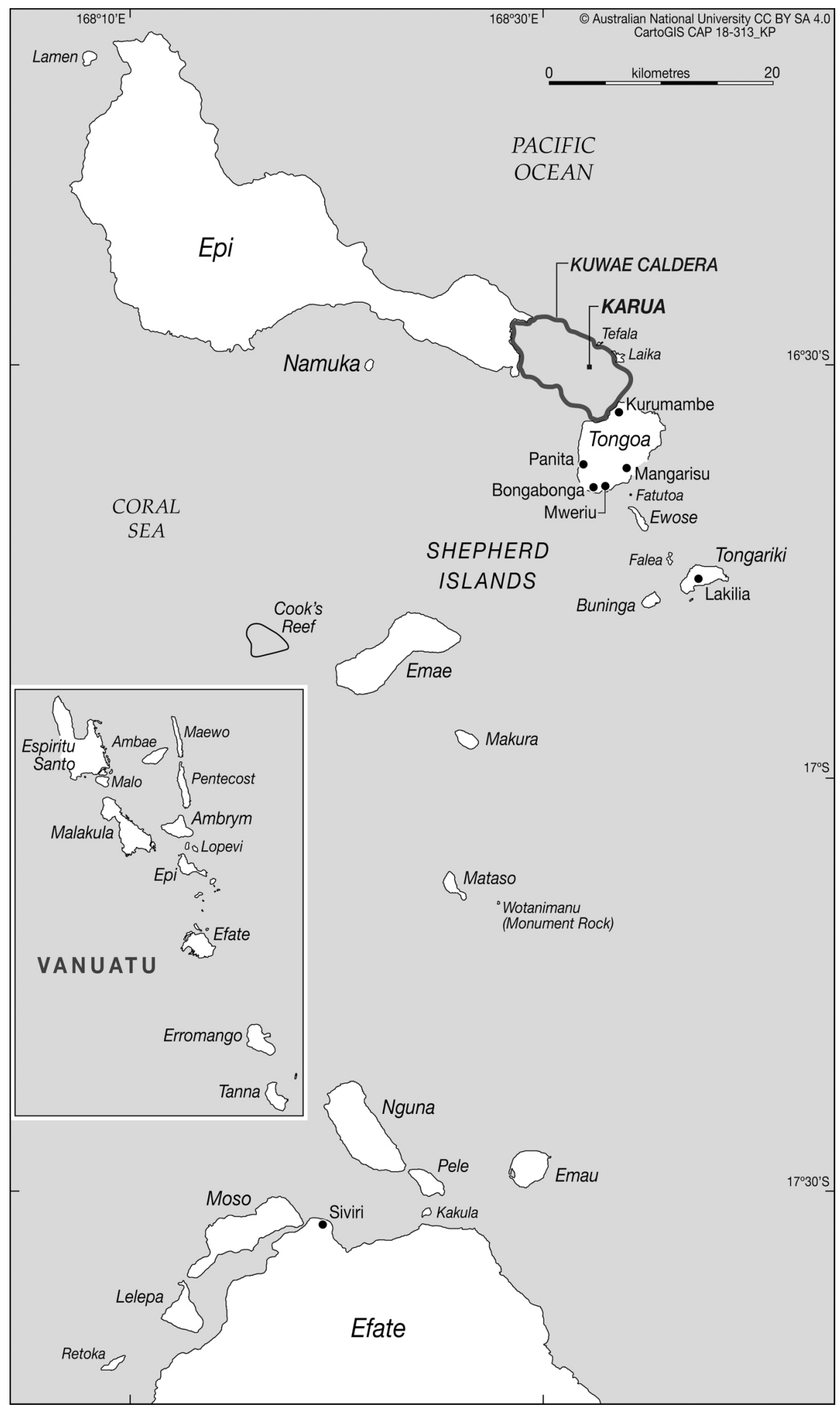


they began to name the ancient villages of Kuwae that were obliterated by the eruption, indicating their approximate locations, also now in the sea. There is a crypto-geography of Kuwae, lying either out to sea or meters beneath the current surfaces of Tongoa and Epi, that has been communicated continuously over the centuries since the eruption and that is widely known even among younger adults today. Narratives of Kuwae mobilize and animate this hidden social geography and link it to present-day concerns and rivalries. Here I briefly review the process through which narratives about Kuwae have become documented and known, and then I trace how-like the dust clouds from the original eruption-they have entered into global circulation.

Not surprisingly, early visitors to Tongoa quickly became aware of the former existence of Kuwae and the nature of its demise. The first missionary to settle on Tongoa, Presbyterian Oscar Michelsen, stayed there from I 879 to I930. He had evidently heard narratives of "Koai" by at least I 890, which was when visitors to his mission first recorded his retellings (Smith I 899, 378). British naval officers surveying the waters off Tongoa on the HMS Dart during I890-189I also referred to oral histories of the eruption (Frederick I893; Somerville I 894, I928), and their close contact with Michelsen again makes it likely that he was the source (Johnston I995, 6I-64). Michelsen himself published multiple composite versions of the two Kuwae stories, first as a summary account blended with his own observations (Michelsen I893, I3-16; compare Michelsen 1934, 232234) and then as a translation of a version of the Tombuku story narrated to him by a Tongoan titled chief, Masiloa (Michelsen I906). ${ }^{3}$

Michelsen's Presbyterian successors on Tongoa, Basil Nottage (I932I939) and Graham Miller (I94I-I947), recorded further versions of the Tombuku and Matanauretonga stories during their periods of tenure (Nottage I988, I26, 258; Miller nd; I98 I, I33, I44-I45). Like Michelsen, they were given artifacts such as pottery and shell adzes recovered from beneath the thick layer of volcanic tephra from the Kuwae eruption,

(Facing page)

Map I The Kuwae Caldera and central Vanuatu. Copyright the Australian National University, College of Asia and the Pacific, CartoGIS. Reproduced with permission. 
which they took as evidence of a keen awareness among living Tongoans of the island's stratigraphy and geological history. They also noted that the presence and distribution on Tongoa of two different languages, Nakanamanga and Namakura, appeared to reflect the oral history of the island's post-Kuwae recolonization. However, their documentation was not widely available until the I980s, and early researchers were probably more influenced by French colonial administrator and scholar Bernard Hébert, who was present in what was then the New Hebrides between I955 and I963. Hébert's inquiries on Tongoa promoted the idea that the oral traditions of Kuwae could be confirmed archaeologically; he documented genealogies, canoe traditions, and archaeological finds, including a sketch of the stratigraphy exposed along the southeastern cliffs near the village of Mweriu on Tongoa, along with the Namakura terms for each layer. Rough estimates by Hébert and his predecessors of the age of the Kuwae eruption, based on their documentation of the number of holders of individual chiefly titles since the event and using an arbitrary average of twenty-five years for each titleholder, ranged widely, from AD I 540 to AD I654 (Hébert I963-I965, 89-90).

Between 1958 and I965, anthropologist Jean Guiart carried out a series of field surveys on Tongoa and the adjacent Shepherd Islands, systematically visiting every settlement of the population of some three thousand people scattered over fourteen islands, in an attempt to map the regional hierarchy of chiefly titles that still extends from Tongoa in the north to Efate in the south (1973, 2013). His documentation of genealogies, oral traditions, and chiefly hierarchies provides a remarkable platform for the reconstruction of regional history before and after the Kuwae eruption. Guiart's corpus of narratives includes a number of detailed versions of both the Tombuku and Matanauretonga stories, told from the perspectives of different villages on Tongoa and other Shepherd Islands.

Guiart's field notes then led his archaeologist colleague José Garanger to Tongoa in 1964 and again in 1966. There, guided and assisted by Tongoans, Garanger excavated several sites, including the exposed pyroclastic layers in the Mweriu cliffs, which yielded uncalibrated radiocarbon results of $\mathrm{AD} I 320 \pm 80$ and $\mathrm{AD} I 460 \pm 37$, providing the first direct dates for the age of the eruption (1972, 1996). Another excavation at the grave of Matanauretonga, known at his death as Ti Tongoa Liseiriki, was dated to $\mathrm{AD}$ I $475 \pm 85$. Drawing on the oral traditions of Matanauretonga's experience of the eruption as a young man and his resettlement of Tongoa, 
Garanger presumed that his burial could have taken place no more than fifty years after the eruption.

Meanwhile, geologists had begun field surveys in the Shepherd Islands, acknowledging the inspiration of the Kuwae stories (Aubert de la Rüe I937; Gèze 1966; Warden 1967; Espirat I973). An early attempt to define the Kuwae crater confirmed local claims that the sea between Tongoa and Epi was the probable location of the eruption (Carney and Macfarlane I977), but it was not until the I990s that a geological team from the Nouméa base of France's Office de la Recherche Scientifique et Technique Outre-Mer (овsтом), led by Jean-Philippe Eissen, Claude Robin, and Michel Monzier, produced the first bathymetric maps of the Kuwae caldera. They concluded that the eruption had been a single event on a vast scale, covering an area of some 60 square kilometers and producing an estimated 32-39 cubic kilometers of ejected material (Eissen, Monzier, and Robin 1994; Monzier, Robin, and Eissen 1994; Robin, Monzier, and Eissen 1994). While few of the geologists directly recorded local narratives of Kuwae, their research would prove instrumental in generating a new, global story about Kuwae.

Since the I960s, linguists, anthropologists, and local historians have documented a fresh wave of versions of the Kuwae stories, mostly recorded in and transcribed from either Nakanamanga or Namakura. Albert Schütz, working on the island of Nguna near Efate, recorded a narrative about refugees from Kuwae sojourning on Nguna and Efate before their return to Tongoa (I969, I85-I95). Jean-Claude Rivierre published transcripts of two intriguingly different versions of the same story of Matanauretonga, told by Willy Kalia and Ti Tongoa Mata of Mangarisu village on Tongoa (1996); a sharp critique of Rivierre's approach by Guiart adds further nuance to the context for the differences in these two versions (20I6). Wolfgang Sperlich, working on the Namakura language of Makura Island, has documented differing versions of the same Matanauretonga story by a single narrator, Mwasoe Ripu of Makura (2014; Sperlich and Masoeripu 2004).

During the I990s, a collaborative team of local historians on Efate and Tongoa, including George Pakoasongi and David Luders, began to record and collate highly detailed oral histories for Tongoa, many of which hinged on the event or the aftermath of Kuwae; some of this material was summarized by Luders in an article (1996) and then in an imaginative, novelized version of the eruption (2010). Most recently, between 20II and 20I9, 
Maëlle Calandra and Sandrine Bessis have recorded, transcribed, and translated several versions of the Tombuku and Matanauretonga stories at Kurumambe on Tongoa and across the Shepherd Islands, respectively (Calandra 2017).

This summary review of the evolution of a corpus of recorded local narratives about Kuwae, now assembled in a single document (Ballard 20I8), prompts a number of preliminary observations. There are obvious genealogies for particular versions or narrative elements that can be attributed to specific paths for transmission among those either narrating or reporting the stories. Early documentation depended largely on narratives recorded or retold by the Presbyterian missionaries living on Tongoa-Michelsen and later Nottage and Miller-as well as those visitors who reported or read their versions. While these earliest documented versions are often reliable in terms of both their rendition of local vernaculars and proper names and their attention to broader contexts for the narratives, the narratives told to these missionaries were often truncated or shorn of details that the same narrators apparently felt able to share with later researchers. For example, Pastor Simbolo, a significant figure as a trained aore or storyteller (Luders nd), provided Miller, his mission superior, with a summary version in the I940s but offered much more detail when approached in 1994 by local historians Pakoasongi and Luders.

This paradox, of narratives recorded more recently being richer in detail than earlier versions, is widely repeated across the collection. The pattern of increasing detail does not appear to be the simple result of invention and elaboration in narratives over time but rather reflects variation in the level of disclosure, matching changes in the nature of the inquiry, the identity of the inquirer, and the degree of attention paid to local vernaculars. Later versions recorded mostly in Nakanamanga or Namakura by professional anthropologists and linguists, from Rivierre and Schütz in the I960s to Sperlich in the r980s and Calandra and Bessis since 20II, are replete with details such as toponyms and precise social relationships that were abridged in many of the early versions. Of course, these later researchers arrived with foreknowledge of Kuwae and were keen to delve more deeply and, following Guiart's lead (I973; $2008, \mathrm{I} 6-\mathrm{I} 7$ ), to record variants of the same stories in as much detail as was available, but perhaps later narrators were also more willing to share such detail in the context of relationships that they saw as less opaque or hierarchical. Before proceeding to analyze the local Kuwae narratives, it is necessary to consider how a new series of stories about Kuwae has 
gone global, if only to appreciate why it is so important to continue to document and interrogate those stories that have their origins in local experience of the event.

\section{"Kuwae” Goes Global}

Other than a few passing references in missionary memoirs and travelogues and in local and regional geological reports, Kuwae was scarcely known of beyond the New Hebrides until I972, when Garanger published his monograph on the archaeology of the central islands. Even within the New Hebrides, stories of the eruption tended to be met with skepticism. R E N Smith of the British administration later recalled that "in our wisdom, we had been inclined to discount New Hebridean tales of this event and how Tongoa had had only one man and one woman survivor; perhaps we thought it some sort of creation myth" (2002, 452). Garanger's writings on Kuwae, published in both French and English between 1972 and I997, brought the eruption to the attention of other archaeologists working in the Pacific and beyond and, perhaps more significantly, stimulated a fresh wave of interest among volcanologists.

The oRsTOM team's assessment of the overlap in age ranges for six radiocarbon dates led them initially to propose the period AD I $420-\mathrm{I} 430$ for the eruption-or, more precisely still, “ $\sim \mathrm{I}_{4} 25 \mathrm{AD}$ " (Monzier, Robin, and Eissen I994, 2II-2I2). But between the submission of this first paper (received by the journal on 3I May 1993) and that of their second paper (Robin, Monzier, and Eissen 1994, received 29 June I993), the ORstom team appears to have become aware of recently published ice core results from Antarctica that identified a strong volcanic sulfate spike in AD I452 (Delmas and others I992). The link appeared plausible, given their estimates of the scale and singularity of the Kuwae eruption, and their second paper duly promoted the new date of AD I 452 .

At this point, we need to distinguish between the Kuwae of local stories and narratives in central Vanuatu and the "Kuwae" of a body of literature on global climate history and the role of major volcanic eruptions in climate change that has burgeoned since the I990s. There is now considerable evidence-registered in tree rings; ice cores from Antarctica, South America, and Greenland; temperature records; and historical documents-for a major volcanic event between about AD I 452 and I 458 , most commonly identified as "Kuwae" (McCarroll and others 20I3; Gao and others 2006; Wang and others 20I2; Zanchettin and others 20I2). More 
recently, some analyses have distinguished between two separate volcanic events, the first in 1453 and the second in 1458 or I 459 (eg, Plummer and others 20I2; Cole-Dai and others 2013; Sigl and others 20I3).

In the immediate aftermath of "Kuwae," AD I 453 was the coldest of the last nine hundred years (Esper and others 20I3). Impacts across the world that have been attributed directly to "Kuwae" include: tsunami impacts across the Pacific (Goff and others 20II); the rupture of the regional flow of people, ideas, and materials (the ritual narcotic kava in particular) between Vanuatu and Western Polynesia (Luders I996); shifts in temperature extremes in eastern Australia (Lippmann 20I2); the Postclassic abandonment of Mayan civilization under the weight of a devastating drought (Gill 2000); exceptionally cold temperatures, epidemics, and famine in China (Atwell 200I); summer snow, famine, and epidemics across Eastern Europe (Kužić 20I2); and even the fall of Constantinople in AD I 453 (Pang I993). This almost romantic enthusiasm has culminated recently in the claim by France's leading medievalist, Patrick Boucheron, that "Kuwae" was the fifteenth century's single most significant event and world history's first truly global event (2OI2, II).

Uncertainties persist over the precise dating of "Kuwae." Recent published claims for the age of the eruption span decades, with suggested approximate dates including I430, I448, I452, I453, I456, I458, and I464 (Siebert, Simkin, and Kimberly 20I0; Kurbatov and others 2006; Esper and others 2015; Gao, Robock, and Ammann 2008; Zanchettin and others 20I2; Sigl and others 20I4; Bauch 20I7). While these might be tolerable discrepancies in direct dating on organic materials, and while they are the subject of ongoing debate about the matching of ice core and tree ring records (Sigl and others 20I 5), they complicate correlation with the more precise documentary historical records available around the world. Finally, almost a quarter of century after the оRsтом publications launched "Kuwae" globally, and in the apparent absence of any subsequent field research confirming their results, researchers have begun to express doubt about the identification of the global phenomenon of "Kuwae" with the eruption in Vanuatu of Kuwae (eg, Guillet and others 20I7; Toohey and Sigl 20I7, 8I3). ${ }^{4}$ For this growing band of skeptics, "Kuwae" is still an eruption in search of a volcano.

The focus of this article on local narratives of Kuwae does not require us to determine the relationship between the local event and the global phenomenon. Other than noting that this vast inverted pyramid of global inference is balanced on a slender peak of direct chronological evidence 
at its point of origin in Vanuatu, I simply want to observe the similarities in the ways that narratives operate at both the global and local levels: the power of competing versions; the circularities of reference among geologists, anthropologists, and archaeologists; and the sense of the stakes at play in this global counterpart to local narrative contestations in Vanuatu.

Narratives of Kuwae touch on matters that are of very real interest today, both to Shepherd Islanders and to outsiders, and there is an understandable urge to seek out further detail and to approach some kind of truth of the events-for Islanders primarily because these narratives are seen to validate present-day claims to titles and land both on Tongoa and on the islands in which they sought refuge after the eruption, and for outsiders because of the significance of claims about the eruption and its global and regional effects. Similar attempts have been made to determine the value for scientists of oral traditions that describe other volcanic eruptions, which, it is assumed, draw on what were presumably original eyewitness accounts. These oral traditions can include details of an event's character, its precursor signs and immediate post-eruption effects, and local strategies for the mitigation of its impacts that might be revived or drawn on for future events (Blong 1982; Cronin and Cashman 2007; Cashman and Cronin 2008).

\section{Remembering Kuwae}

In a recent jeremiad, historian David Henige derided almost all attempts to find evidence in oral traditions for cataclysmic events in the deep-time past, which he took to be anything earlier than about 150 years before the first documentation of a particular narrative (2009, 232). His critical comments had been provoked by claims for the oral transmission of memories of major cataclysms thousands or even tens of thousands of years in the past. Quite reasonably, Henige pointed out that these claimswhether accurate or not-are not readily subjected to any kind of test. But he then extended his criticism to all "oral societies," which, in his view, "subordinate historicity to social concerns" and inevitably reproduce eyewitness memories (the "original texts") of geological events "in garbled form" (Henige 2009, I42, I 53, I90, 223). He also referred briefly to Kuwae, casting doubt on the precise date of the event by citing the early genealogical estimates but not the available radiocarbon results (Henige 2009, 22 I-222). Setting aside Henige's questionable characterizations of transmission in "oral societies" and his assumption of a unique register 
of historicity against which all historical accounts should be measured (see Ballard 20I4), there is evident value in adopting a cautious and thorough approach to the analysis of the Kuwae stories and narratives rather than accepting them uncritically as some form of direct access to historical events of the fifteenth century.

As with all oral traditions (and perhaps all histories), local articulations of the Kuwae stories observe local narrative conventions, attribute agency and moral responsibility to different characters, and are recruited and modified to conform to particular social and political needs and circumstances, which are themselves constantly in flux. They convey certain kinds of information about the past, but in a manner that requires a considerable grasp of context and a degree of restraint in interpretation (see Evans, this issue). They were certainly never conceived as "texts," whether as the immutable expression of a single truth or as alternate versions of a single originary text, to be fixed on the page and then compared hermeneutically, line by line, with each other. Instead, they are expressions of a knowledge that is variably distributed and acutely aware of its own incompleteness. They are endlessly refined in the retelling, in perpetual quest for a completeness that might accord perfectly with present-day needs-an inevitably chimeric goal that guarantees their ongoing vitality and further evolution. All narratives are versions and are understood as such. ${ }^{5}$

Why should Kuwae be so memorable for Tongoans? In Tongoan oral tradition, the eruption was a unique event, with no precursor or successor of comparable scale, and current geological and archaeological knowledge supports this claim over the three millennia of human occupation of the region (Bedford 2007; Stuart Bedford, pers comm 2019). The eruption thus serves as a highly significant chronological marker locally, but it is set within histories that reach back far earlier in time. Long-term research on four senior chiefly titles from southern Tongoa has identified between forty-eight and fifty-two holders for each title, extending back to the first titleholder's arrival from the south by canoe (Luders I996, 294). Titleholders are ideally related through direct descent, but in practice, most titles have passed through more complex routes, and the resulting genealogies for each title are not a reliable basis for chronological estimates. For each of these four titles, however, the eruption occurred just twentytwo to twenty-three generations before the present holder-that is to say, less than halfway back through the sequence of titleholders (note that this genealogical depth for the eruption is considerably greater than those that Hébert and his predecessors proposed earlier). In Tongoan conception, the 
history of initial settlement on Kuwae is thus longer than the subsequent, post-eruptive history of Tongoa. Narratives invoked in disputes still touch on the pre-eruptive history and the sequence of arrivals of the first holders of each title, but they are much more closely concerned with the second wave of canoe traditions, in which surviving titleholders or their successors arrived to lay claim to the new islands of Tongoa and Tongariki.

In addition to the position of Kuwae within Tongoan historical sequences, there are material forms of proof of the eruption and its consequences. For Tongoans, the transformation of the landscape is brute evidence of the eruption's force, and they also point to the thick layer of reworked tephra visible in sea cliffs around Tongoa and eastern Epi, with obvious evidence for pre-eruptive settlements in the form of pottery and stone and shell artifacts lying immediately beneath the tephra. Individual title lineages retain their own forms of proof: ancient groves of trees planted by the first recolonizers, the grave sites of their first chiefs, and mnemonic stones arranged in serpentine lines on the sites of the earliest posteruptive settlements, each stone in a particular series corresponding to an individual holder of the particular title. ${ }^{6}$

If all these forms of proof were not sufficient in themselves, there is still the lizard, which continues to stir. The major submarine vent known to geologists as Karua and to many Tongoans as Tombuku continues to erupt. Since the arrival of Michelsen on Tongoa in I 879, Karua is known to have erupted during I897, I900-I90I, I906, I923-I925, I948, I949, I952, I958, I959, I971, I972, I974, I977, I979, and I980 (Eissen, Blot, and Louat I99I, 43-44; Siebert, Simkin, and Kimberly 2010). Each eruption of Karua triggers further transmission of knowledge about Kuwae and signals to living Tongoans the possibility of a future major event; in this way, the stories of Tombuku and Matanauretonga continue to resonate and to be retold.

\section{Tombuku's Revenge}

The first of the two principal Kuwae stories revolves around the character of Tombuku, the man who created and unleashed the volcano to purge his shame and that of his mother. While it is known and recounted widely across the Shepherd Islands, the Tombuku story is in some sense owned, or at least told with the strongest sense of conviction, by the people of Kurumambe village on Tongoa, who are the direct descendants of the survivors of Tombuku's village and those closest today to the vent of Karua/ 
Tombuku. The summary that follows incorporates those elements common to most renditions of the story, indicating some of the key variations. ${ }^{7}$

A young man, Tombuku (also known as To'obuk, To'ombuk, Tombuk, Topuku, Taumbuku, Pae, or Bae), lived at Tanomalala on the island of Kuwae (Koai or Kuai in Nakanamanga and Kua in Namakura). There, either his prowess as a hunter or his will to best his age mates in competition led them to trick him into sleeping with his widowed mother in a small house or an enclosure set within a men's house. In the dark, he recognized the cicatrices on her skin and swore to avenge himself on the village youth. He joined a canoe leaving for the island of Lopevi (also Lupepe, Lubebe, Lumbarae), or in some variants distant Ambrym, where he sought the advice of his maternal uncle. Together, they concocted a package of fearsome power: a small lizard (green, white, or blue-tailed or, in one narrative, a bird) within a hollowed-out yam (and with or without other magical materials such as hair from a red pig or from the uncle). In some versions, the power of this magical bundle was so great that Tombuku's canoe sank or barely held together on the return journey to Kuwae. Once back at Tanomalala, Tombuku buried the yam and the lizard at the base of a large casuarina tree in the center of the village. Killing six pigs in a succession of feasts, he removed and inflated their bladders, which he hung from the branches of the tree. At a final feast attended by all, he burst each of the bladders in turn, provoking successively stronger earthquakes each time. As the final bladder burst, the ground beneath the tree erupted in flame, and Kuwae was torn apart by the lizard's power. Tombuku died instantly, and his decapitated head was hurled across the sea to land at his uncle's feet.

The Tombuku narratives follow the actions of a single protagonist, locating the cause of the eruption in Tombuku's agency, in his shame. Incest, even if inadvertent, is perhaps the only moral offense appropriate in scale to the magnitude of his revenge. Brought from Lopevi to Kuwae, an island with no previous history of volcanic activity, Tombuku's lizard introduces in condensed form the potency of the Lopevi volcano. In the alchemy of Tongoan narratology, Tombuku is the agent, while the lizard is a reagent-a nameless and timeless power that endures to this day. The bursting of the six bladders is widely interpreted on Tongoa as marking time intervals-of days, months, or years-during which precursor eruptions or earthquakes caused a large part of the population of Kuwae to flee. Today, we know only of survivors who fled south to the other Shepherd Islands or further to Efate and its nearshore islands of Nguna and 
Emau; this suggests either that Kuwae's strongest ties lay to the south, among other communities within today's hierarchical network of chiefly titles, or that those who fled north did not survive in significant numbers.

Guiart referred to the Tombuku story as "the tradition from the North" (2013, 445), reflecting its orientation from former settlements on the north coast of Kuwae toward their natural exchange partners in Lopevi and Ambrym. The series of six pig-kills and the display of their inflated bladders on different levels of a tree are more reminiscent of grade-taking ceremonies to the north than they are of any of the former feasting practices recalled today in the Shepherd Islands or farther south (Bonnemaison I996). But there is also a practical, affective link being proposed between the eruptive center on Kuwae and the active volcanoes of the closer, visible islands of Lopevi and Ambrym, which are 50 kilometers and 80 kilometers to the north, respectively, rather than the nearest active volcano to the south, Yasur on Tanna, which is 300 kilometers distant (see map I, inset). Certainly, northern Tongoa was recolonized later than the southern coast, presumably because it was adjacent to and more powerfully reduced by the eruption; and yet the communities of northern Tongoa speak Nakanamanga, a language from northern Efate and its nearshore islands, to which they trace their immediate origins (Clark 1996). An important annex to the Tombuku story is the story of the flight of the son of Taripoa Mata, the senior chief of Kurumambe, to Siviri in North Efate (Calandra 20I8), and many other stories related to specific chiefly titles extant today describe similar movements south before returning to Tongoa (eg, Schütz I969, I8 5-I95). If the Tombuku narratives play a broader political role today, it is in accounting for the delayed recolonization of northern Tongoa by people from Efate, now speaking Nakanamanga, in comparison with the earlier return of the first Namakura-speaking chiefs from the nearby Shepherd Islands to the southern part of the new island, led by Matanauretonga.

\section{Matanauretonga’s Return}

Narratives about Matanauretonga and his return to Tongoa are more widely retold and more variable in their detail—and thus more diverse in their significance and implications-than the Tombuku narratives. ${ }^{8}$ The Matanauretonga narratives begin just before Tombuku's story ends, with a young man, Asingmet (Simeti, Smet), checking his traps along the beach in southeastern Kuwae. When the volcano exploded to his north, Asing- 
met fled southward, pursued by the flames along the continuous coastline that extended down toward Tongariki-today the small rock of Fatutoa between Tongoa and Ewose marks the line of this former coastline and is often identified as the location of his traps. Reaching the settlement of Lakilia on Tongariki, he took refuge in a large standing slit gong drum. There he was found by the island's only other survivor, Tarifekit-an older woman in most versions but still young in others-who had hidden in a cave. Together they searched for and found breadfruit buried in pits, which enabled them to survive until they were rescued by Tarimasu of Makura Island, who saw their fires by night.

At this point, the Matanauretonga narratives begin to diverge from one another because the relationships forged on Makura during this period, along with the sequence of returns to Tongoa and Tongariki, are critical to contemporary political contestation, which hinges on questions of priority and prerogative. Almost everything about these relationships is disputed, including Asingmet's parentage, the identity and origins of his wife, and the nature of his debt to Tarimasu of Makura. What is common to all versions is that Asingmet, now known as Matanauretonga ("the first on the island of Tong[o]a"), married and returned to southern Tongoa, where he settled at Bongabonga and received the title Ti Tongoa or Ti Tongoa Liseiriki. As the first on the land, Matanauretonga marked land boundaries by planting trees, such as the large nakuma'ir (tree of life) said to have been brought by him from Makura and often referred to as grafts from his walking stick (Miller nd, I9I).

These common elements enable all audiences to recognize the basic story, but the narrative variations are critical. Makuran versions stake a claim to Tongoan titles and land by claiming either that Asingmet's wife was Nawa, Tarimasu's daughter, or that Tarifekit herself (or Nawa as her daughter with Asingmet) was ceremonially impregnated by the chiefs of Makura (Guiart 1973, 57). Tongariki versions claim stronger ties to Tongariki for Matanauretonga (Guiart 20I3, 448f), while Tongoan versions allow for little of this external input but differ in their understanding of what happened to Ti Tongoa Liseiriki's twin sons and their titles, Ti Tongoa Mata and Ti Tongoa Roto, once established on Tongoa (Guiart I973, I66f; Rivierre 1996).

An additional degree of local interest in Ti Tongoa Liseiriki was generated through the excavation of his grave by Garanger in I966 (I972, 92-94). Garanger's AD I $475 \pm 85$ date on bone collagen further confirmed 
for him the relationship between the oral tradition and the eruption, while details of the body ornaments in the grave confirmed the truth of the oral traditions for the Tongoan chiefs present at the excavation, including the then holder of the Ti Tongoa Mata title. Rivierre's comments on the Matanauretonga narratives neatly capture this enmeshment of past events and present concerns: "As we have seen ... the central characters of this history bear the same names as their descendants who are narrating the stories or participating in the archaeological excavations. In evoking these characters, the informants speak of the present, of themselves, of their land and political claims; in short, of vital stakes, for them as individuals and for their groups" (Rivierre I996, 440; my translation).

The local Kuwae stories may tell us little about the actual event of the eruption, but they are expansive on its moral and social causes and consequences. What must have been a multitude of eyewitness experiences of the eruption has become condensed over time into two distinct storiesthe Matanauretonga story told largely in the Namakura language by people from Makura, Tongariki, and southern Tongoa, which deals with the early moments of recolonization of Tongoa, and the Tombuku story told largely in the Nakanamanga language by survivors from northern Kuwae (now based in Kurumambe and other villages of northern Tongoa), who returned much later to this more devastated part of Tongoa. Most Shepherd Islanders know the general outline of both stories, but, in keeping with their village affiliations, local narrators tend to confine their renditions to either one or the other, rarely running from one to the next unless prompted to do so. It is only in the retellings by outsiders that the two stories are assembled together in an attempt to produce a comprehensive history of the eruption (eg, Michelsen I 893; Guiart 20I3, 445; Garanger I972, 85; Luders 2010). One intriguing and for now unexplained distinction between the two stories is the presence in the story of Tombuku, but not that of Matanauretonga, of chanted songs, interspersed throughout, which extend and supplement the narrative while also conferring a degree of authenticity on the narration (eg, Michelsen 1906; Miller nd; Guiart I973, I66).

The two Kuwae stories have become communal memories of the event, with further details or embellishments added depending on the narrator's particular position and intent and on the composition of the audience on 
each occasion of their retelling (see Evans; Kim, this issue). Understanding the relationship between the stories—as tales that are broadly recognized and locally accepted as historically true-and their individual renditions as particular narratives helps us to appreciate how and why such variation is introduced.

But there is also much more to Tongoan histories of Kuwae than the stories of Tombuku and Matanauretonga. Genealogies, place-names, sections of histories from other chiefly titles and other islands, and artifacts such as fragments of the original canoes on which people returned to Tongoa combine to create a rich context for the formal narratives, setting them within the materiality of landscapes, artifacts, and the living themselves (as forms of proof for the genealogies). It may be possible to piece together a local history - or rather histories - of the eruption and its aftermath from these fragments, adding precious flesh to the bare bones of archaeological and geological reconstruction, but that has never been the impetus driving the stories' transmission in the Shepherd Islands. Local stories about Kuwae, situated within a communally accepted narrative framework that is itself externally grounded in material forms of proof, are told not in order to historicize or date the eruption but rather to account for its origins and to validate particular positions in the present. The interest now being expressed in the events of Kuwae through a new kind of story, the global history of "Kuwae," is likely to evoke still more detail and elaboration in the local narratives.

THE RESEARCH REPORTED HERE HAS BEEN SUPPORTED By funding from the Firebird Foundation, the Australian National University, and the Equipe d'Accueil Sociétés Traditionnelles et Contemporaines en Océanie (EASTCO) Laboratory of the University of French Polynesia. I thank the Tongoa Council of Chiefs and the Maraki Vanua Riki (the Shepherd Islands Council of Chiefs) for their permission to conduct preliminary research on Kuwae, and Abet Marias, Alice Kaloran, Marie Shem, and John Lee Solomon Te Buninga for arranging a series of meetings with chiefs and communities of the Shepherd Islands in 2010 and 20I7. Over a longer period, I have been guided and greatly aided by David Luders, George Pakoasongi, and Jean Guiart. I am grateful to Maëlle Calandra and Sandrine Bessis for their comments on a draft version of this article and for their generous sharing of their recordings and transcripts, to Karina Pelling for her fine map, and to Matthew Spriggs and the guest editors of this special issue for their constructive comments on a draft. 


\section{Notes}

I The contrast drawn here between "story" and "narrative" is unconventional in the context of analysis of oral traditions, where the terms tend to be deployed as synonyms (see, eg, Tonkin I992; Cruikshank I998), but it does accord with Gérard Genette's distinction between story as content and narrative as discursive act ( I980, 27, I 56n87).

2 The collated narratives-none of which I recorded myself-were first recorded or documented between I 890 and 2018 and were collected in the Shepherd Islands or on Efate in central Vanuatu, formerly the New Hebrides. The format in which I received them ranged from audio recordings to published and unpublished stories and interview transcripts.

3 Johnston reproduced the original manuscript of Michelsen's text, which suggests that the published version was poorly transcribed (Johnston I995, appendix 2).

4 For a popular summary of these doubts, see Gorvett 2017.

5 On narratives as versions, see Neumann 1992 and Schieffelin and Crittenden I99I.

6 In many respects, these features of Tongoan historicity conform closely with documented accounts of the relationship between oral tradition and material proof elsewhere in the Pacific region (eg, Firth I96I; Latouche I984; Reilly 2009; Kirch 20I 8).

7 Published transcripts of Tombuku narratives were provided by Guiart (I973, 263f; 2013, 462-463) and Tom Tipoamata (2005).

8 For published transcripts of Matanauretonga narratives, see Guiart I973, 57f; 20I3, 45If; Rivierre I996; Sperlich 2014.

\section{References}

Atwell, William S

200I Volcanism and Short-Term Climatic Change in East Asian and World History, c.I 200-I 699. Journal of World History I 2 (I): 29-98.

Aubert de la Rüe, Edgar

I937 Le volcanisme aux Nouvelles Hébrides (Mélanésie). Bulletin Volcanologique 2 (I): 79-I42.

Ballard, Chris

20I4 Oceanic Historicities. The Contemporary Pacific 26 (I): 96-I 24.

Ballard, Chris, compiler

2018 Kuwae Narratives: Sources on the Kuwae Eruption. Unpublished manuscript, last modified July 20I 8, copy in author's files. 
Bauch, Martin

2017 The Day the Sun Turned Blue: A Volcanic Eruption in the Early I460s and Its Possible Climatic Impact-A Natural Disaster Perceived Globally in the Late Middle Ages? In Historical Disaster Experiences: Towards a Comparative and Transcultural History of Disasters across Asia and Europe, edited by Gerrit Jasper Schenk,

Bedford, Stuart I07-I 38 . Heidelberg: Springer.

2007 Pieces of the Vanuatu Puzzle: Archaeology of the North, South and Centre. Terra Australis 23. Canberra: ANu Press.

Blong, Russell J

I982 The Time of Darkness: Local Legends and Volcanic Reality in Papua New Guinea. Canberra: ANU Press.

Bonnemaison, Joël

I996 Graded Societies and Societies Based on Title: Forms and Rites of Traditional Power in Vanuatu. In Arts of Vanuatu, edited by Joël Bonnemaison, Christian Kaufmann, Kirk Huffman, and Darrell Tryon, 200-216. Bathurst: Crawford House Publishing.

Boucheron, Patrick

2012 Introduction: Les boucles du monde: contours du XVe siècle. In Histoire du monde au XVe siècle, edited by Patrick Boucheron, I:9-45. 2 volumes. Paris: Pluriel.

Calandra, Maëlle

2017 Jardins de Terre, Jardins de Mer à Tongoa (Vanuatu). Une anthropologie de la nature domestique dans un milieu affecté par la catastrophe. PhD dissertation, École des Hautes Études en Sciences Sociales, Paris.

20I 8 Histoire du Tompuku, racontée par Tari Liu (Willy Henry) du namatana ni farea Undapua. Recorded by Maëlle Calandra, 5 December 2013, Kurumampe Village, Tongoa. In Kuwae Narratives: Sources on the Kuwae Eruption, compiled by Chris Ballard. Unpublished manuscript, last modified July 20I 8, copy in author's files.

Carney, J N, and A Macfarlane

I977 Submarine Geology, Epi-Tongoa. In Annual Report of the Geological Survey for the Year 1975, I I-I3. Port Vila: New Hebrides Geological Survey.

Cashman, Katharine V, and Shane J Cronin

2008 Welcoming a Monster to the World: Myths, Oral Tradition, and Modern Societal Response to Volcanic Disasters. Journal of Volcanology and Geothermal Research I76 (3): 407-4I8.

Clark, Ross

I996 Linguistic Consequences of the Kuwae Eruption. In Oceanic Cul- 
ture History: Essays in Honour of Roger Green, edited by Janet Davidson, Geoffrey Irwin, Foss Leach, Andrew Pawley and Dorothy Brown, 275-285. Dunedin North: New Zealand Journal of Archaeology.

Cole-Dai, Jihong, David G Ferris, Alyson L Lanciki, Joël Savarino, Mark H Thiemens, and Joseph R McConnell

2013 Two Likely Stratospheric Volcanic Eruptions in the I45Os C.E. Found in a Bipolar, Subannually Dated 800 Year Ice Core Record. Journal of Geophysical Research: Atmospheres II 8 (I4): 7459-7466.

Cronin, Shane J, and Katharine V Cashman

2007 Volcanic Oral Traditions in Hazard Assessment and Mitigation. In Living under the Shadow: The Cultural Impacts of Volcanic Eruptions, edited by John Grattan and Robin Torrence, I75-202. Walnut Creek, CA: Left Coast Press.

Cruikshank, Julie

I998 The Social Life of Stories: Narrative and Knowledge in the Yukon Territory. Lincoln: University of Nebraska Press.

Delmas, Robert J, Severine Kirchner, Julie M Palais, and Jean-Robert Petit

I992 Iooo Years of Explosive Volcanism Recorded at the South Pole. Tellus B 44 (4): 335-350.

Eissen, Jean-Philippe, C Blot, and Rémy Louat

I99I Chronologie de l'activité volcanique historique de l'arc insulaire des Nouvelles-Hébrides de I 595 à I99I. Sciences de la Terre, Géologie-Géophysique, Rapports Scientifiques et Techniques 2. Noumea: ORSTOM.

Eissen, Jean-Philippe, Michel Monzier, and Claude Robin

I994 Kuwae, l'éruption volcanique oubliée. La Recherche 25 (270): I 200I 202.

Esper, Jan, Lea Schneider, Paul J Krusic, Jürg Luterbacher, Ulf Büntgen, Mauri Timonen, Frank Sirocko, and Eduardo Zorita

20I3 European Summer Temperature Response to Annually Dated Volcanic Eruptions over the Past Nine Centuries. Bulletin of Volcanology $75: 736$, I-I 4 .

Esper, Jan, Lea Schneider, Jason E Smerdon, Bern R Schöne, and Ulf Büntgen

2OI 5 Signals and Memory in Tree-Ring Width and Density Data. Dendrochronologia 35:62-70.

Espirat, Jean-Jacques

I973 Etude géologique de l'île Tongariki et observations sur la géologie des îles Shepherd. In Système des titres, électifs ou héréditaires, dans les Nouvelles-Hébrides centrales d'Efate aux îles Shepherd, edited by Jean-Jacques Espirat, Jean Guiart, Marie-Salomé Lagrange and 
Monique Renaud, I-45. Paris: Institut d'ethnologie, Musée de l'Homme.

Firth, Raymond

I96I History and Traditions of Tikopia. Polynesian Society Memoir 33. Wellington: The Polynesian Society.

Frederick, G C

I 893 Geological Notes on Certain Islands in the New Hebrides. Quarterly Journal of the Geological Society 49:227-232.

Gao, Chaochao, Alan Robock, and Caspar Ammann

2008 Volcanic Forcing of Climate over the Past I,500 years: An Improved Ice Core-Based Index for Climate Models. Journal of Geophysical Research II3 (D23II).

Gao, Chaochao, Alan Robock, Stephen Self, Jeffrey B Witter, J P Steffenson, Henrik Brink Clausen, Marie-Louise Siggaard-Andersen, Sigfus Johnsen, Paul A Mayewski, and Caspar Ammann

2006 The I 452 or I 453 A.D. Kuwae Eruption Signal Derived from Multiple Ice Core Records: Greatest Volcanic Sulfate Event of the Past 700 Years. Journal of Geophysical Research I I I (D I 2 I07).

Garanger, José

1972 Archéologie des Nouvelles-Hébrides: contribution à la connaissance des îles du centre. Publications de la Société des Océanistes 30. Paris: ORSTOM.

I996 Tongoa, Mangaasi and Retoka: History of a Prehistory. In Arts of Vanuatu, edited by Joël Bonnemaison, Christian Kaufmann, Kirk Huffman, and Darrell Tryon, 66-73. Bathurst: Crawford House Publishing.

Genette, Gérard

I980 Narrative Discourse. Translated by Jane E Levin. Oxford: Basil Blackwell.

Gèze, Bernard

I966 Sur l'âge des derniers cataclysmes volcano-tectoniques dans la région centrale de l'arc des Nouvelles-Hébrides. Bulletin de la Société Géologique de France $\mathrm{S}_{7}$-VIII (2): 329-333.

Gill, Richardson Benedict

2000 The Great Maya Droughts: Water, Life, and Death. Albuquerque: University of New Mexico Press.

Goff, James, Catherine Chagué-Goff, Dale Dominey-Howes, Brian McAdoo, Shane Cronin, Michael Bonté-Grapetin, Scott Nichol, Mark Horrocks, Marco Cisternas, Geoffroy Lamarche, Bernard Pelletier, Bruce Jaffe, and Walter Dudley 20I I Palaeotsunamis in the Pacific Islands. Earth-Science Reviews I07 (I-2): I4I-I46. 
Gorvett, Zaria

2017 The Massive Volcano that Scientists Can't Find. ввс, 3 July. http:// www.bbc.com/future/story/20I 70630-the-massive-volcano-that -scientists-cant-find [accessed 5 June 20I9]

Guiart, Jean

I973 Le dossier rassemblé. In Système des titres, electifs ou héréditaires, dans les Nouvelles-Hébrides centrales d'Efate aux îles Shepherd, by Jean-Jacques Espirat, Jean Guiart, Marie-Salomé Lagrange, and Monique Renaud, 47-365. Paris: Institut d'ethnologie, Musée de l'Homme.

2008 Myth in the Islands of the Central Pacific. In Sexual Snakes, Winged Maidens and Sky Gods: Myth in the Pacific: An Essay in Cultural Transparency, edited by Serge Dunis, I I-49. Nouméa: Le Rocher-àla Voile.

2013 Cultures on the Edge: Caught Unwittingly between the White Man's Concepts of Polynesia Opposed to Melanesia, From Efate to Epi, Central Vanuatu. Pape'ete: Te Pito o te Fenua.

2016 Jean-Claude Rivierre: Histoire de Matanauretong (Tongoa). Unpublished manuscript, copy in author's files.

Guillet, Sébastien, Christophe Corona, Markus Stoffel, Myriam Khodri, Franck Lavigne, Pablo Ortega, Nicolas Eckert, Pascal Dkengne Sielenou, Valérie Daux, Olga V Churakova (Sidorova), Nicole Davi, Jean-Louis Edouard, Yong Zhang, Brian H Luckman, Vladimir S Myglan, Joël Guiot, Martin Beniston, Valérie Masson-Delmotte, and Clive Oppenheimer

20I7 Climate Response to the Samalas Volcanic Eruption in I 257 Revealed by Proxy Records. Nature Geoscience Io (2): I23-I 28.

Hébert, Bernard

I963-I965 Contribution à l'étude archéologique de l'île Éfaté et des îles avoisinantes. Études Mélanésiennes I 8-20:7 I-98.

Henige, David

2009 Impossible to Disprove Yet Impossible to Believe: The Unforgiving Epistemology of Deep-Time Oral Tradition. History in Africa

Johnston, Ewan C 36:1 27-234.

I995 "Cannibals Won for Christ": Oscar Michelsen, Presbyterian Missionary in the New Hebrides, I878-1931. MA thesis, University of Auckland.

Kirch, Patrick Vinton

20I 8 Voices on the Wind, Traces in the Earth: Integrating Oral Narrative and Archaeology in Polynesian History. Journal of the Polynesian Society I $27(3): 275-306$. 
Kurbatov, A V, G A Zielinski, N W Dunbar, P A Mayewski, E A Meyerson, S B Sneed, and K C Taylor

2006 A I2,000 Year Record of Explosive Volcanism in the Siple Dome Ice Core, West Antarctica. Journal of Geophysical Research II I (DI 2307): I-I 8 .

Kužić, Krešimir

2012 The Impact of the Eruption of the Kuwae Volcano of I452/I 453 on Croatian Lands. Historijski Zbornik 30:I09-I 2 I.

Latouche, Jean-Paul

I984 Mythistoire tungaru: Cosmologies et genéalogies aux îles Gilbert. Paris: Société d'Études Linguistiques et Anthropologiques de France.

Lippmann, Tanya

2012 Natural and Anthropogenic Drivers of Australian Temperature Extremes, Simulated over the Last Millennium. Honors thesis, University of New South Wales, Sydney.

Luders, David

I996 Legend and History: Did the Vanuatu-Tonga Kava Trade Cease in A.D. I 447? Journal of the Polynesian Society I05 (3): 287-3 I0.

20 Iо Cataclysm. Saga of Pacific Islands 3. Limerick: RealTime Publishing. nd A Portrait of Simbolo. Unpublished manuscript, copy in author's files.

McCarroll, Danny, Neil J Loader, Risto Jalkanen, Mary H Gagen, Håkan Grudd, Björn E Gunnarson, Andreas J Kirchhefer, Michael Friedrich, Hans W Linderholm, Markus Lindholm, Tatjana Boettger, Sietse O Los, Sabine Remmele, Yuri M Kononov, Yasuhiro H Yamazaki, Giles H F Young, and Eduardo Zorita

2013 A I200-Year Multiproxy Record of Tree Growth and Summer Temperature at the Northern Pine Forest Limit of Europe. The Holocene 23 (4): 47I-484.

Michelsen, Oscar

I893 Cannibals Won for Christ: A Story of Missionary Perils and Triumphs in Tongoa, New Hebrides. London: Morgan \& Scott.

I906 Old Maliloa's Story about Taumbaka and the Land of Koai. The New Hebrides Magazine I9:6-9.

I934 Misi. London: Marshall, Morgan \& Scott.

Miller, J Graham

I98I Live: A History of Church Planting in the New Hebrides, Now the Republic of Vanuatu, to I 880 . Book 2. Sydney: Presbyterian Church.

nd Field Notes from Tongoa, New Hebrides, I94I-I947. Рмв I025. Canberra: Pacific Manuscripts Bureau, Australian National University.

Monzier, Michel, Claude Robin, and Jean-Philippe Eissen

I994 Kuwae (»I425 A.D.): The Forgotten Caldera. Journal of Volcanology and Geothermal Research 59:207-2 I8. 
Neumann, Klaus

I992 Not the Way It Really Was: Constructing the Tolai Past. Honolulu: University of Hawai'i Press.

Nottage, Basil C

I988 Break of Day Islands: The New Hebrides Diary of Basil Nottage, I932-I939, edited by J Graham Miller. Wellington: Presbyterian Church of New Zealand.

Pang, Kevin D

I993 Climatic Impact of the Mid-Fifteenth Century Kuwae Caldera Formation, as Reconstructed from Historical and Proxy Data. Abstract. Eos, Transactions of the American Geophysical Union 74 (43): 106.

Plummer, C T, M A J Curran, T D van Ommen, S O Rasmussen, A D Moy, T R Vace, H B Clausen, B M Vinther, and P A Mayewesi

2012 An Independently Dated 2000-Yr Volcanic Record from Law Dome, East Antarctica, Including a New Perspective on the Dating of the I 45 OS CE Eruption of Kuwae, Vanuatu. Climate of the Past 8:I929I940.

Reilly, Michael P J

2009 Ancestral Voices from Mangaia: A History of the Ancient Gods and Chiefs. Auckland: The Polynesian Society.

Rivierre, Jean-Claude

I996 Mythistoire et archéologie dans le Centre-Vanuatu. L'histoire de Matanauretong (Tongoa). In Mémoire de Pierre, mémoire d'homme: Tradition et archéologie en Océanie, edited by Michèle Julien, Michel Orliac, Catherine Orliac, Bertrand Gérard, Anne Lavondès, Henri Lavondès, and Claude Robineau, 43 I-463. Paris: Publications de la Sorbonne.

Robin, Claude, Michel Monzier, and Jean-Philippe Eissen

I994 Formation of the Mid-Fifteenth Century Kuwae Caldera (Vanuatu) by an Initial Hydroclastic and Subsequent Ignimbritic Eruption. Bulletin of Volcanology 56:170-I83.

Schieffelin, Edward L, and Robert Crittenden

I99I Like People You See in a Dream: First Contact in Six Papuan Societies. Stanford, CA: Stanford University Press.

Schütz, Albert J

I969 Nguna Texts: A Collection of Traditional and Modern Narratives from the Central New Hebrides. Oceanic Linguistics Special Publication 4. Honolulu: University of Hawai'i Press.

Siebert, Lee, Tom Simkin, and Paul Kimberly

2010 Volcanoes of the World. Third edition. Washington, DC: Smithsonian Institution.

Sigl, Michael, Joseph R McConnell, Lawrence Layman, Olivia Masell, Ken 
McGwire, Daniel Pateris, Dorther Dahl-Jensen, Joren Peder Steffensen, Bo Vinther, Ross Edwards, Robert Mulvaney, and Sepp Kipfstuhl

2013 A New Bipolar Ice Core Record of Volcanism from WAIs Divide and NEEM and Implications for Climate Forcing of the Last 2000 Years. Journal of Geophysical Research: Atmospheres I I 8: I I 5 I-I I 69.

Sigl, Michael, Joseph R McConnell, Matthew Toohey, Mark Curran, Sarah B Das, Ross Edwards, Elisabeth Isaksson, Kenji Kawamura, Sepp Kipfstuhl, Kirstin Krüger, Lawrence Layman, Olivia J Maselli, Yuko Motizuki, Hideaki Motoyama, Daniel R Pasteris, and Mirko Severi

2014 Insights from Antarctica on Volcanic Forcing During the Common Era. Nature Climate Change 4:693-697.

Sigl, M, M Winstrup, J R McConnell, K C Welten, G Plunkett, F Ludlow, U Büntgen, M Caffee, N Chellman, D Dahl-Jensen, H Fischer, S Kipfstuhl, C Kostick, O J Maselli, F Mekhaldi, R Mulvaney, R Muscheler, D R Pasteris, J R Pilcher, M Salzer, S Schüpbach, J P Steffensen, B M Vinther, and T E Woodruff

2015 Timing and Climate Forcing of Volcanic Eruptions for the Past 2,500 Years. Nature 523:543-549.

Smith, George Adam

I 899 The Life of Henry Drummond. London: Hodder \& Stoughton.

Smith, R E N

2002 R. E. N. Smith: Administrative Officer, I96I-I967. In Tufala Gavman: Reminiscences from the Anglo-French Condominium of the New Hebrides, edited by Brian Bresnihan and Keith Woodward, 449-472. Suva: Institute of Pacific Studies, University of the South Pacific.

Somerville, Henry Boyle Townshend

I 894 Notes on Some Islands of the New Hebrides. Journal of the Anthropological Institute of Great Britain and Ireland 23:2-2 I, 363-393.

I928 The Chart-Makers. Edinburgh: William Blackwood \& Sons.

Sperlich, Wolfgang B

20I4 Phoenix Rising from the Ashes: Kuwae, the Story in na-Makir (Central Vanuatu). Wolfgang B Sperlich-Old but New (blog), 23 March. http://wolfgangsperlich.blogspot.com/2014/03/phoenix-rising-from -ashes-kuwae-story.html [accessed 5 June 20I9]

Sperlich, Wolfgang B, and Edson Masoeripu

2004 Kuwae, the Story in Namakir. Paper presented at Sixth International Conference on Oceanic Linguistics, Emalus Campus, University of the South Pacific, Port Vila, Vanuatu, 4-9 July.

Tipoamata [Tipoloamata], Tom

2005 Kuwae Aelan. Vanuatu Daily Post, 5 November. 
Tonkin, Elizabeth

I992 Narrating Our Pasts: The Social Construction of Oral History. Cambridge, uk: Cambridge University Press.

Toohey, Matthew, and Michael Sigl

2017 Volcanic Stratospheric Sulfur Injections and Aerosol Optical Depth from 500 BCE to I 900 CE. Earth System Science Data 9 (2): 80983 I.

Wang, Tao, Odd Helge Otterå, Yongqi Gao, and Huijun Wang

2012 The Response of the North Pacific Decadal Variability to Strong Tropical Volcanic Eruptions. Climate Dynamics 39:2917-2936.

Warden, A J

I967 The Geology of the Central Islands. New Hebrides Geological Survey Report 5. New Hebrides: British Service.

Zanchettin, D, C Timmreck, H-F Graf, A Rubino, S Lorenz, K Lohmann, Kirstin Krüger, and J H Jungclaus

2OI2 Bi-Decadal Variability Excited in the Coupled Ocean-Atmosphere System by Strong Tropical Volcanic Eruptions. Climate Dynamics 39:4I9-444.

\section{Abstract}

Stories of a massive volcanic eruption that destroyed the island of Kuwae in what is now central Vanuatu have been told and retold over centuries. The two most prominent local stories focus not on the eruption itself but rather on the events leading up to it and on its social consequences as survivors returned to the newly created island of Tongoa. Led by these local stories to explore the history of Kuwae, researchers have generated new stories that describe the global impacts of a mid-fifteenth-century eruption that may have contributed to the onset of the Little Ice Age. But the local stories about Kuwae, embedded within communally accepted narrative frameworks that are themselves externally grounded in material forms of proof, are told not to historicize or date the eruption but rather to account for its origins and to validate particular positions in the present. Understanding the different needs driving local and global stories of Kuwae is a prerequisite for bringing them together within a single frame of analysis.

KEYWORDS: history, story, narrative, volcanic eruption, Kuwae 